\title{
European Experience of University Business Cooperation for Sustainable Development
}

\author{
E. V. Viktorova ${ }^{1}$, D. A. Petrenko ${ }^{2}$, D. A. Gorulev ${ }^{3}$ \\ Saint Petersburg State University of Economics \\ St. Petersburg, Russia \\ 1elena.viktorova@mail.ru, ${ }^{2}$ dariia.petrenko.1@gmail.com, ${ }^{3}$ gorulev@ finec.ru
}

\begin{abstract}
The article is devoted to the role of cooperation between universities and business in achieving Sustainable Development Goals. The programs and innovative strategies of the European Union aimed at stimulating cooperation are analyzed and presented. As a result, it was concluded that the "triple helix" is the most promising model of cooperation, the principles of which are the basis of the European programs "Knowledge Alliances" and "Knowledge and Innovation Communities".
\end{abstract}

Keywords- Sustainable Development University Business Cooperation; Knowledge alliances; Knowledge and Innovation Communities (KICs)

\section{INTRODUCTION}

On September 25, 2015, Member States Of the United Nations adopted the 2030 Agenda for Sustainable Development. The agenda was designed to improve the life quality and the future for all people around the world. Achieving the Sustainable Development Goals (SDGs) requires the joint efforts of governments, business, civil society and the entire population of the Earth.

Achieving the SDGs requires the full participation of all stakeholders: business, the general public, educational institutions, civil society and each person. [3]

Sustainable Development Goals cover three dimensions: economic, social and environment. Moreover, the social sphere has the largest share, it covers $52.44 \%$ of the SDGs, the economic sphere $-27.25 \%$, and the environment $-25.31 \%$. [4]

A University is one of the actors in achieving the SDGs. It provide and develope necessary experience, knowledge and skills for students so that in the future they can make both individual and collective decisions at the local, regional and global levels, which will contribute to improving the quality of life without harming the environment. In this context, a University directly or indirectly affects the achievement of all 17 SDGs. However, university education mostly covers the following Goals:

- $\quad$ SDG 4 - Quality education;

- $\quad$ SDG 8 - Decent Work and Economic Growth

- $\quad$ SDG 9 - Industry, Innovation, and Infrastructure. [3]

\section{EUROPEAN STRATEGIES AND PROGRAMS FOR} SUPPORTING UNIVERSITY BUSINESS COOPERATION

After the economic crisis of 2008, the pace of economic development in European countries decreased and level of unemployment increased. In the SDGs, these indicators are given a special place, as they are directly related to many other indicators and goals. One of the ways to solve this problem and create the conditions for sustainable economic development is to build a new economic strategy based on knowledge, the socalled "Knowledge Economy". This strategy is included in the European program of economic development "Europe 2020". It involves significant changes in the training process and in the higher education system as a whole. [7]

The modern paradigm of the "Knowledge Economy" development strategy in Europe is based on stimulating the development of innovation and innovative entrepreneurship, which is not possible without close cooperation between universities and business.

Universities are holders of knowledge. Business has the necessary material and technical basis for putting this knowledge and innovations into practice. Considering of these facts one of the directions of European economic policy is to stimulate various aspects in cooperation between universities and companies. [11]

Thus, according to the "Economics of Knowledge" strategy, three main stakeholders are involved in education:

- $\quad$ public authorities interested in improving the quality of education, reducing of unemployment level, improving the social environment and the development of the city / region / country, etc.;

- HEIs that are also interested in improving the quality of education, as well as in increasing the demand for the university, attracting additional funding, developing scientific activities, etc.;

- business whose interest is increasing productivity and efficiency, attracting highly qualified staff and accessing to the research base of universities, etc. [2]

Such a model of interaction is called the "triple helix" and is one of the priority areas for the development of the "Knowledge Economy". Ideally, University Business Cooperation (UBC) should be supported by authorities. [1] 
State support can be provided at all levels: from local to interregional and international. Thus, in the European Union there are a number of programs that provide financial support for University Business cooperation in various aspects.

- The program "Horizon 2020" (2014-2020) and its successor, "Horizon Europe" (2021-2027) - research and innovation frameworks, major EU programs that specifically support research and innovation. The programs support:

- $\quad$ key areas to support research and innovation and their targeted impact;

- European partnership;

- international cooperation.

The program provides financing by a wide range of tools and measures, such as supporting and financing public and private partnerships, as well as specific tools that support research and innovation in small and medium-sized businesses.

"Horizon" is an open program, in which an organization can take part from almost any state. However, participants in the EU Framework Program are divided into three types:

- Members of the European Union (EU MSs);

- Associate Participants (AP): Albania, Israel, Iceland, Liechtenstein, Macedonia, Montenegro, Norway, Serbia, Turkey, Switzerland, Bosnia and Herzegovina, Faroe Islands, Moldova, Ukraine, Georgia;

- $\quad$ Third countries (Not EU MSs and APs).

Russia belongs to the category of countries that can participate in Horizon projects, but are not eligible for financial support from the program budget. [7]

- The COSME program, with an annual budget of $€$ 2,298 million, offers tools that support the creation and expansion of companies, especially with a view to expanding research activities with universities. [8]

- The Erasmus + program aims to support collaboration in education, vocational training, youth, and sports. The program integrated such previously existing programs as: The LifeLong learning Programme, The Youth in Action programme, The Erasmus Mundus Programme, Alfa, Edulink, Tempus и другие. [6]

\section{A. Knowledge Alliances}

A significant program under Erasmus + is the Knowledge Alliances program, which creates international consortium, that include universities, employers and authorities from different countries and even regions with the goal of intercultural and interinstitutional knowledge exchange. The overall goal is to help strengthen Europe's innovation potential, promote cooperation between universities and business, and support the modernization of higher education systems in Europe. In addition, the activities of the "Knowledge Alliances" are aimed at:
- development of new, innovative and multidisciplinary approaches to education,

- $\quad$ stimulating entrepreneurship and entrepreneurial skills of university graduates and company employees,

- knowledge exchanging and join investigation.

The consortiums participating in the Knowledge Alliances program receive a grant, the maximum amount of which can reach 700,000 euros for 2 years and 1,000,000 euros for 3 years. Each consortium must consist of at least six independent organizations from three countries participating in the Program, including at least two universities and two companies (state or private enterprises, including social enterprises). For example, in 2019, 31 consortiums received funding.

In addition to them, the consortium may include:

- Research institutes;

- State authorities at local, regional or national level;

- Education institutions;

- Association of educational, training or youth institutions;

- Business association;

- Accreditation, certification or qualification body. [9]

The activities of consortium can be carried out in various fields: education in general, medicine and healthcare, information technology, entrepreneurship, social activities, engineering, ecology, textiles, etc.

\section{B. European Institute of Innovation \& Technology}

A unique European initiative is the European Institute for Innovation and Technology (EIT). This is an independent organization of the European Union, whose activities are aimed at increasing the competitiveness of Europe by stimulating the development of innovation, entrepreneurial skills and the support of new ideas. The Institute's activities are funded by the Horizon 2020 and Horizon Europe Programs' Funds.

Within the framework of the institute, Knowledge and Innovation Communities (KICs) were created. Such Communities are partnerships whose activities are aimed at enhancing the interaction between business, universities and research centers. Communities work in Innovation hubs. Currently there are more than 50 hubs. They are distributed throughout the territory of the European Union in order to increase the influence of the European Institute of Innovation and Technology.

KICs operate in eight areas (Fig. 1). [10]

As part of Horizon Europe program, it is planned to create two new Communities of Knowledge and Innovation:

- The first one will be focused on the cultural and creative industries; its' opening is planned in 2022;

- The area of the second Community has not yet been determined; its' launch is planned in 2025. 

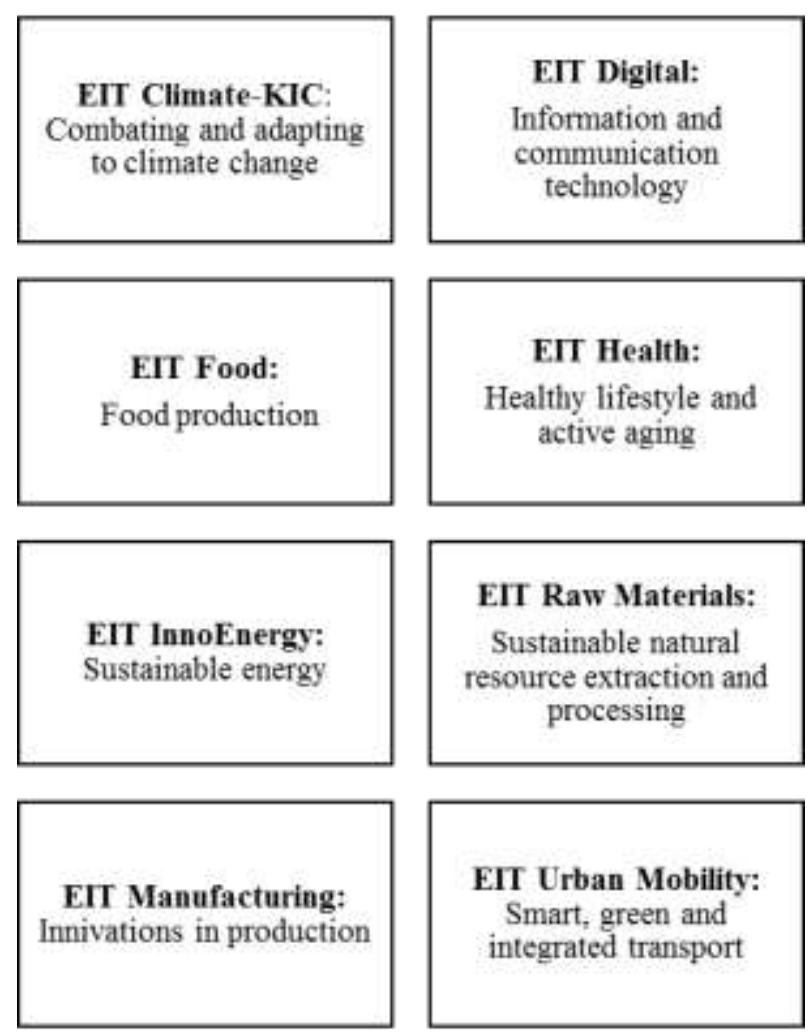

Fig. 1. Areas of KICs activity

In addition, Communities will also develop links with Smart Specialization strategies, an EU initiative to stimulate economic growth and create jobs that allows each region to identify and develop its own competitive advantages. It is planned to involve more universities, enterprises and research organizations at the regional level in the network.

Moreover, during the period from 2021 to 2027, the European Institute of Innovation and Technology will provide support in financing, expert knowledge and training at 750 universities, which will allow them to develop economic activities in the field of their interests. Most of the funding will go to universities from countries with low innovative potential. [5]

\section{CONCLUSION}

Universities, business and government are among the main actors in accelerating the development of innovative processes in the Knowledge Economy. In a modern knowledge-based economy, the need for cooperation between the three actors has particular importance. This process is extremely important for high-tech sectors of the economy, which, in turn, are the locomotive, source and generator of innovation. In addition, innovations contribute to sustainable growth of the economy as a whole, creation of new jobs, employment and the achievement of Sustainable Development Goals.
Thus, the main tendencies in innovations in education and economy in Europe are:

1. Formation of "Knowledge Alliances", uniting universities, companies and other organizations with the aim of developing entrepreneurship and innovative activity in any field;

2. Creation of Knowledge and Innovation Communities (KIC), aimed at introducing and developing innovations in eight main areas.

These initiatives are being actively developed and supported by European funds, so there are reasons to conclude that such models of interaction between universities, business and government will become a solid foundation for the sustainable development of Europe.

\section{REFERENCES}

[1] Ickovic G. Model' trojnoj spirali [Triple Helix Model] Innovacii. [Innovation] 2011. No. 4. URL: https://cyberleninka.ru/article/n/modeltroynoy-spirali (viewed 14.10.2019) (In Russian)

[2] Viktorova E.V., Gorulev D.A., Zaynullina A.B. Sotrudnichestvo universitetov $i$ rabotodatelej $s$ cel'yu obespecheniya kachestva $i$ aktual'nosti obrazovaniya: rezyume issledovaniya. [Universities and employers collaborating to ensure the quality and relevance of education: research summary] St. Petersburg.: Publishing House of ETU "LETI". 2018. 27 p. (In Russian)

[3] Sustainable Development https://www.un.org/sustainabledevelopment/ru/sustainabledevelopment-goals/

[4] Cutter A, Osborn D, Romano J., Ullah F. Sustainable development goals and integration: Achieving a better balance between the economic, social and environmental dimensions, final report of the United Nation's Open Working Group (OWG). Stakeholder Forum. 2015. URL.: sf.stakeholderforum.org/index.php/news/617-sustainable-developmentgoals-sdgs-and-integration-achieving-a-better-balance-between-theeconomic-social-and-environmental-dimensions(viewed 14.10.2019)

[5] EIT Strategy 2021 - 2027: URL.: https://eit.europa.eu/who-we-are/eitglance/eit-strategy-2021-2027 (viewed 14.10.2019)

[6] Erasmus+: URL.: https://ec.europa.eu/programmes/erasmusplus/node_en (viewed 14.10.2019)

[7] Europe 2020. A European strategy for smart, sustainable and inclusive growth:

URL. http://ec.europa.eu/eu2020/pdf/COMPLET\%20EN\%20BARROSO\%20 $\% 20 \% 20007 \% 20-\%$ 20Europe $\% 202020 \% 20-\% 20$ EN\%20version.pdf (viewed 14.10.2019)

[8] European Parliamentary Research Service. Overview of EU Funds for research and innovation. 2015: URL.: http://www.europarl.europa.eu/RegData/etudes/BRIE/2015/568327/EPR S_BRI\%282015\%29568327_EN.pdf (viewed 14.10.2019)

[9] Knowledge Alliances: URL.: https://eacea.ec.europa.eu/erasmusplus/actions/key-action-2-cooperation-for-innovation-and-exchangegood-practices/knowledge-alliances_en (viewed 14.10.2019)

[10] Knowledge and Innovation Communities: URL. https://eit.europa.eu/activities/innovation-communities (viewed 14.10.2019)

[11] Viktorova E.V. Analysis of university and business cooperation models in Europe. 6th IEEE forum strategic partnership of universities and enterprises of hi-tech branches (Science. Education. Innovations), SPUE 2017. Pp. 111-113. 